\title{
Effects of Rural Urban Migration on Labour Supply in Cocoa Production in Ondo East Local Government Area of Ondo State
}

\author{
Lawal, A. S. \\ Okeowo, T. A.
}

School of Agriculture, Lagos State Polytechnic, Ikorodu

Doi:10.5901/ajis.2014.v3n7p25

\begin{abstract}
The study was conducted to examine the effect of rural urban migration on labour supply in cocoa production. Data were collected from one hundred farmers in Ondo East Local Government area of Ondo state. Five villages were selected from which twenty respondents were randomly selected making a total of 100. Descriptive statistics and multiple regression analysis used for analysis of data. The study revealed that people migrate for social, educational and economic reasons. Based on this, the study recommends that rural areas should be developed so as to make it more habitable for the rural people as this will discourage emigration.
\end{abstract}

Keywords: Migration, Rural-urban, Production, Labour supply, Cocoa, Ondo

\section{Introduction}

Migration, which is referred to as the movement of people from one area to another will affect labour force available for agricultural production. It is certain that agricultural production will not take place in the absence of labour input. Labour is regarded, as human effort, both physical and mental, required in production for a reward. There is mass rush of labour from rural area to urban area. This has resulted in high unemployment rate since the non-agricultural sectors are yet to be in position of absorbing these migrants. Development in highly needed to ensure that people earn good living from agricultural sector in order to reduce the migration of youths out of the rural areas.

In Nigeria, it has been found that lack of an opportunity to earn ready cash income during the slack season in the farming calendar has engendered migration among Hausa farmers, (Ekong, 1988). Sometimes too, rural-urban wage differential may generate migration. This was the case in Nigeria during the colonial days when the introduction of export cash crops like cocoa and rubber into South Western Nigeria drew migrant farmers from other parts of the country into this region.

Nearly all migration studies tend to conclude that people migrate primarily for economic opportunities between urban and rural regions the greater the flow migrants from rural to urban areas. Insufficiency of land within the farmers own village or ethnic territory has also been found to generate migration. This is particularly so among the Ibo people. In other words, Ibo from land-scarce villages usually migrate to settle and farm in the areas where land is plentiful, (Ekong, 1988).

In addition to economic motive, people migrate to improve their education or skills-which is equally an economic motive in the long run. People with higher education in rural area tend to move out to find commensurate employments in the towns. People also migrate to escape from social and cultural imprisonment in homogenous rural areas. Those who are a little more enlightened as a result of the acquisition of some formal education would want to see more of the world beyond their village boundaries.

The innovators who want something new and different are generally fired by this motive to migrate, (Ekong, 1988). The need to escape from social upheavals, violence, political instability, suspected or real persecution may also lead to migration in either urban-rural, rural-urban, or rural directions. Adverse physical conditions in the environment such as drought, land slide.

Erosion or earthquake, flood, menace insect pests, infertility of the soil, exhaustion of pasture (in the case of normadic cattle rearers) have made people of move to less perilous geographical locations. The influx of aliens from the Niger Republic into Nigeria in the 1970's was partly due to the Sahelian drought. Similarly in part of Udi, Nsukka and Awka in Anambra State, the problem of soil infertility was aggravated by gully erosion which destroyed houses and farms 
to the extent that some villages in Awka area particularly, had to be abandoned under the Agulu soil conservation scheme of 1945, (Ekong, 1988). Those affected by the disaster had to migrate to other parts of the country to established as tenant farmers.

In Nigeria, the development of road transportation and improved communication systems have equally contributed to the growth and spread of migrant farmers. Apart from enabling them to travel long distances within a day, road have opened up new areas for settlement and facilitated access to markets for migrant farmer. Rural-urban migration remains as important development in Nigeria. Rural-urban migration of potential farmers reduces the absolute number of workforce available within a family. It has a serious effect on the production of food and cash crops in the country.

Tomori (1995), emphasized that the Nigerian civil war between 1967 and 1970, the increase in petroleum revenue, the consequent ability of government to finance large construction projects in urban centres, as well as migration of able bodied men (youths) from rural to urban centres all contributed to reduction in agricultural production since 1973.

\section{Effects of Migration}

Like any other social phenomenon, migration has its positive as well as negative consequences or effect both on the sources or donor region and the destination area. On the negative side, it is often held that migration from rural into urban areas tend to deplete the agricultural labour force as it is the able-bodied young men who usually move. With no commensurate substitution of capital in place of the displaced labour, agricultural productivity tends to fall in the source regions. However, this negative effect can only be fully evident in cases where out-migration is on a permanent or long term basis.

The other negative effects of migration on urban areas particularly, include the strain it puts on existing urban services such as water supply, transportation, health facilities and general sanitation, housing and unemployment opportunities. Rural-rural migration in Nigeria has been known to generate initial hostility at some destination regions. Such hostility may arise as a result of the failure of the migrant to keep the terms of agreement on the conditions of tenancy, attempts by the migrant to Usurp land rights, disregard for the power structure of the host community and other social problems.

On the positive side, migration affords the opportunity for the migrants to acquire new skills and broaden their intellectual and social horizons. Return migrants often stimulate cultural innovations and technological changes in their home communities. For instance, it was the returning Irun-Ekiti migrant farmers from Ife and Ibadan coca farms who introduced cocoa to their district at the end of the second world was, thereby transforming a former source region into an important absorption area for migrants from other areas including Igira food producers, Hausa kola traders, Isoko oil palm exploiters and some Ibo labourers, (Ekong, 1988). Similarly the early adopters of rice cultivation in the Abakaliki area were migrant farmers. This crop was equally introduced into the Elu Elu district of the Cross River plains by Afikpo migrant tenant farmers. Thus rural-rural migrant farmers in Nigeria have successfully converted a number of otherwise food deficit areas into surplus food producing regions. (Ekong, 1988).

Migrants also provide labour (often cheap labour) to a wide variety of economic activities in their destination including serving as house helps, daily- paid casual labourers at construction sites. Perhaps the other very important effect of migration is that of mutual cultural diffusion which takes place between the migrants and their hosts.

Movements of people from rural to urban areas have been identified to be one of the major reasons why agricultural production is still low despite the vast resources that abound in the country. Rural -urban migration is known to have adverse effect on farm labour supply, which will consequently reduce farm output. Hence, there is need for further studies on rural-urban migration. It is imperative to examine the causes and the effects of rural-urban migration on labour supply since agricultural production depends on labour supply. This becomes more useful especially if increase in agricultural production is to be attained in the nearest future. Infact, agricultural production cannot take place without human labour. It is for this reason that the study becomes more important and relevant. The study also intends to come out with policy recommendation, which may serve as reference material to agricultural scientists.

\section{Objectives of the Study}

1. To present empirical evidence of the effects of rural-urban migration on labour supply.

2. To determine the rate of out migration in the study area.

3. To make policy recommendation based on the findings. 


\section{Methodology}

The study was conducted in Ondo East Local Government area of Ondo State. Ondo East Local Government is bounded by Edo and Delta States. Ondo East lives in the rainforest Zone of Nigeria. Majority of the inhabitants engage in agriculture. The population of the area is predominantly Yoruba speaking tribes. Arable crops such as maize, yam, rice, tomatoes, beans, plantain, cassava, and cash crops such as timber, cocoa, rubber, kolanut, palm tree etc are the major crops planted in the area. There are two raining seasons, i.e wet and dry season. The wet season commence from April and last in October, while dry seasons commence from November and last in March and there is august break, which is usually marked with a period of low rainfall.

The study was carried out in Ondo East Local Government area. The following villages: Ureje, Oboto, Igbo-oja, Ago Store and Lagbawo were visited. Twenty copies of questionnaire were administered on farmers in each of the five villages to retrieve information on socio-economic variables. One hundred questionnaires were randomly administered. Both primary and secondary data were used. The primary data were collected through the use of questionnaire consisting of both close and open ended questions. The secondary data were obtained from journals, published articles, and relevant texts. Analytical techniques such as descriptive statistics and econometric method, using the ordinary least square. (OLS) estimation were employed.

\section{Model Specification}

The model shows certain variables that are considered to have effect on migration of young able - bodied. It is implicitly expressed as:

$\begin{array}{ll}Y= & F(X 1, X 2, X 3, X 4, X 5, X 6) \\ \text { Where: } & \\ Y= & \text { Total number of migrants } \\ X 1= & \text { Labour (Mandays) } \\ X 2= & \text { Land } \\ X 3= & \text { Seed } \\ X 4= & \text { Credit } \\ X 5= & \text { Availability of Electricity } \\ X 6= & \text { Error term }\end{array}$

There functional forms were used to test the effect of rural- urban migration on labour supply. The functional forms are as follows:

Linear Function

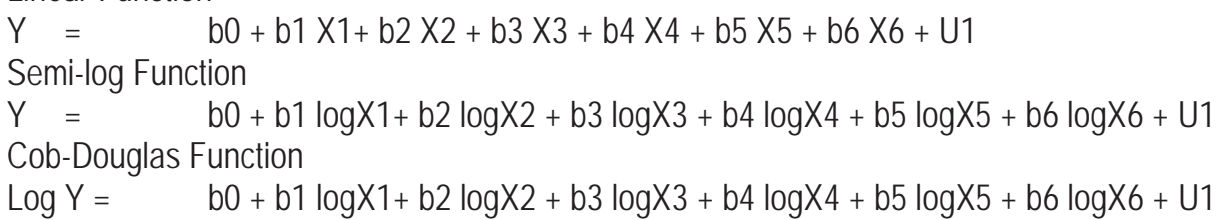

\section{Results and Discussion}

\subsection{Socio-economic Characteristics}

Table 4.1 shows that $9 \%$ of the farmers were between 41 and 50 years $48 \%$ of the farmers were between 51 and 60 years while $43 \%$ of the farmers were between 61 years and above. This indicates a large percentage of the farmers were old. This also shows that few youth engage in farming which suggests that there might have been rural-urban migration of youths to pursue educational goal, non-agricultural employment and other economic opportunities, the situation which deprives the rural areas of able bodies and energetic labour force. This also shows that $100 \%$ of the sampled farmers were male. This shows that male engaged in farming than females in the study area. This also suggests that female in these area engaged in other enterprises such as trading. The reason for the above result in terms of male dominating cocoa production could be because of energy demanding nature of the enterprises, which the female many not be able to cope with.

Table 4.1 showed that the reveals that $87 \%$ of the sampled farmers were married, $13 \%$ were divorced. This 
signified that majority of farmers in the study area are married. This also indicates that farmers will employ more hands on the farm. This will consequently increase farm output (cocoa production). The table also showed that $11 \%$ of the respondents had household size of between 0 and 5 people while $77 \%$ had between $6-11$ people. $12 \%$ had between 12 and 12 respectively. The above result showed that cocoa production require more labour which could only provided by the family. According to the table, $36 \%$ of the sampled farmer had no formal education while $59 \%$ had primary education, $5 \%$ had secondary education. This implies that largest percentage of respondents in the study area are illiterates. This may also prevent them from adoption innovation that will increase production and productivity.

The table also showed that $20 \%$ of farmers in the study area had no access to good road to convey their products to the market, while $80 \%$ of the sampled farmers had access to good road. This means that more than half of the localities have access to good road that may probably reduce the influence of rural-urban migration. Although access to good roads alone may not be the factor for checking rural-urban migration social infrastructures such as health water and electricity. The table also revealed that $27 \%$ of the sampled farmers were not using improved inputs on their farms while $73 \%$ used improved input. The above result indicates an effective extension system in areas of cocoa production, which is likely to give positive impact in terms of increased in yield. This shows that reveal $52 \%$ increase in the movement of people from their village to the town, $35 \%$ indicates that there was no change in the rate of people moving to the town while $13 \%$ indicates a decrease in outflow of people from their village to the town. The result confirms that existence of rural-urban migration in the study area with an attendant labour shortage for farming activities. This may have serious implication on the labour force available for cocoa production.

According to the table, $80 \%$ of the sampled farmers indicated that schools in the community are not far, while $20 \%$ show that the schools are far from the village in the study areas.

The above result showed that very few of the cocoa producers' children will be available to provide supplementary labour during the week days. However, the children will be available on weekends to assist their parents on the farm. This showed that $85 \%$ of the sampled area had their clinics within their areas, while $9 \%$ had their clinic far from their village, $6 \%$ respondents could not decide. The above result indicated that the respondents in the study area will be able to take advantage of the nearness of health facilities since health facilities are near to them.

The table also revealed that $84 \%$ of the respondents had their boreholes within their village. $13 \%$ of the respondents had their houses far from the bore-hole. $3 \%$ of the respondents could not decide. With the larger percentage of the respondents indicating the nearness to borehole, it is likely to improve accessibility to hygienic water source. However observation of the borehole showed majority of which are not functional. The table also showed that $5 \%$ of the respondents spend between 2,000 and 3,900 man days, $41 \%$ of the sampled farmers spent between 4,000 and 5,900 man days, $42 \%$ of the sampled farmers spent between 6.000 and 7,900 man days, $10 \%$ of the sampled farmers spent between 8,000-9,900 man days, while $2 \%$ spent more than 10,000 man days on hired labour. This means that farmers spend more on hired labours to replace family-member that has moved out. This also reduced farmer's net income. Labour usually charge between N200-N250 per day and stays on the farm for period of at least 8 hours. This also showed that $80 \%$ of the sampled area had electricity, but not regular while $20 \%$ had no electricity. The irregular supply of electricity will encourage rural urban migration in the study area.

Table 4.1: Socio-economic Features of Respondents ( $N=100)$

$\begin{array}{lcc}\text { Age } & \text { Frequency } & \text { Percentage } \% \\ 41-50 & 9 & 9 \\ 51-60 & 48 & 48 \\ 61 \text { and above } & 43 & 43 \\ \text { Total } & 100 & 100 \\ \text { Sex } & \text { Frequency } & \text { Percentage \% } \\ \text { Female } & - & - \\ \text { Male } & 100 & 100 \\ \text { Total } & 100 & 100 \\ \text { Marital status } & \text { Frequency } & \text { Percentage \% } \\ \text { Single } & - & - \\ \text { Married } & 87 & 87 \\ \text { Divorced } & 13 & 13 \\ \text { Total } & 100 & 100\end{array}$




Household size
$0-5$
6-11
12-17
18 and above
Total
Types of Education
Non-formal
Primary
Secondary
Tertiary
Total
Access to Good Road
No
Yes
Total
Improved inputs
No
Yes
Total
Change in population
Increase
No change
Decrease
Total
Distance to school
Not too far
Far
Total
Distance to clinic
Not too far
Far
Undecided
Total
Distance to bore-hole
Not too far
Far
Undecided
Total
Man days
0-1,900
2,000-3,900
4,000-5,900
6,000-7,900
8,000-9,900
Above 10,000
Total
Electricity
No
Yes
Total

\begin{tabular}{|c|c|}
\hline Frequency & Percentage $\%$ \\
\hline 11 & 11 \\
\hline 77 & 77 \\
\hline 12 & 12 \\
\hline - & - \\
\hline 100 & 100 \\
\hline Frequency & Percentage \% \\
\hline 36 & 36 \\
\hline 59 & 59 \\
\hline 5 & 5 \\
\hline - & - \\
\hline 100 & 100 \\
\hline Frequency & Percentage $\%$ \\
\hline 20 & 20 \\
\hline 80 & 80 \\
\hline 100 & 100 \\
\hline Frequency & Percentage $\%$ \\
\hline 27 & 27 \\
\hline 73 & 73 \\
\hline 100 & 100 \\
\hline Frequency & Percentage $\%$ \\
\hline 52 & 52 \\
\hline 35 & 35 \\
\hline 13 & 13 \\
\hline 100 & 100 \\
\hline Frequency & Percentage $\%$ \\
\hline 80 & 80 \\
\hline 20 & 20 \\
\hline 100 & 100 \\
\hline Frequency & Percentage \% \\
\hline 85 & 85 \\
\hline 9 & 9 \\
\hline 6 & 6 \\
\hline 100 & 100 \\
\hline Frequency & Percentage \% \\
\hline 84 & 84 \\
\hline 13 & 13 \\
\hline 3 & 3 \\
\hline 100 & 100 \\
\hline Frequency & Percentage \% \\
\hline- & - \\
\hline 5 & 5 \\
\hline 41 & 41 \\
\hline 42 & 42 \\
\hline 10 & 10 \\
\hline 2 & 2 \\
\hline 100 & 100 \\
\hline Frequency & Percentage \% \\
\hline 20 & 20 \\
\hline 80 & 80 \\
\hline 100 & 100 \\
\hline
\end{tabular}

Source: Field survey,2012

\subsection{Regression Result and Interpretation}

Multiple regression model was used to evaluate the degree in which certain variables influence rural-urban migration. The number of migrants obtain was used as the dependent variable, while the independent variable include the following; Labour (X1), Land (X2), Seed (X3), Credit (X4), Electricity (X5), and Borehole (X6). The linear, semi log, Cobb Douglas 
has functional forms of the production function were employed using least square technique (OLS).

Linear Function: $Y=b 0+b 1 X 1+b 2 X 2+b 3 X 3+b 4 X 4+b 5 X 5+b 6 X 6+U 1$

Semi log: $Y=b 0+b 1 \log X 1+b 2 \log X 2+b 3 \log X 3+b 4 \log X 4+b 5 \log X 5+b 6 \log X 6+U 1$

Cobb Douglas: $Y=b 0+b 1 \log X 1+b 2 \log X 2+b 3 \log X 3+b 4 \log X 4+b 5 \log X 5+b 6 \log X 6+U 1$

\subsection{Lead Equation Selection}

Cobb Douglas (Double log) was considered as lead equation based on statistical and econometric criteria. Econometric criteria talked about science and magnitude whereas statistical method is concerned about $\mathrm{R}_{2}$.

Table 4.2 Cobb-Douglas Regression Analysis

$\begin{array}{ccccc} & \begin{array}{c}\text { Regression } \\ \text { Co-efficient }\end{array} & \begin{array}{c}\text { Standard } \\ \text { Error }\end{array} & \text { t-value } & \text { Remarks } \\ \text { Constants } & 3.510 & 2.163 & 1.623 & \\ \text { LOGX }_{1} & -.102 & .090 & -1.134 & \mathrm{R}_{2}=0.774 \\ \text { LOGX }_{2} & .758 & .188 & 4.035 & \mathrm{~F}=11.520^{*} \\ \text { LOGX }_{3} & .248 & .138 & 1.797 & \mathrm{~S} . \mathrm{E}=1.895 \mathrm{E} .02 \\ \text { LOGX }_{4} & .242 & .125 & 1.931 & \\ \text { LOGX }_{5} & .268 & .344 & .780^{*} & \\ \text { LOGX }_{6} & -.184 & .272 & -.676 & \\ *=\mathrm{t} \text { - value significant at } 5 \% \text { Alpha level, }{ }^{*}=\mathrm{F} \text { - value significant at 5\% Alpha level. }\end{array}$

Table 4.2 showed an inverse relationship between dependent variable $Y$ (total migrants) and independent variable $X_{1}$ (labour in man days). The implication is that any increase or decrease in independent variable $X_{1}$ (Labour) will have an inverse effect on dependent variable $(Y)$, which is migration. In other words, an increase in rural-urban migration will reduce total number of labour available for agricultural production, and this will consequently reduce farm output as well as farmers income. The independent variable, borehole $\left(X_{6}\right)$ also showed negative influence on dependent variable $Y$ (Total migrants). The implication of this is that inadequate water supply in the study area encouraged rural -urban migration. Other variables land $\left(X_{2}\right)$ seeds $\left(X_{3}\right)$ credit $\left(X_{4}\right)$ showed positive relationship with the dependent variable (Total migrants).

\subsection{Zero-Order Correlation Matrix for the Variable}

The Zero-order correlation between the dependent and independent variables is shown below.

\begin{tabular}{|c|c|c|c|c|c|c|}
\hline Log $Y$ & $\begin{array}{l}\log Y \\
1.000\end{array}$ & $\log X_{1}$ & $\log X_{2}$ & $\log X_{3}$ & $\log X_{4}$ & $\log X_{5}$ \\
\hline $\log X_{1}$ & $.313^{* \star}$ & 1.000 & & & & \\
\hline $\log X_{2}$ & $.601^{*}$ & $.492^{\star \star}$ & 1.000 & & & \\
\hline $\log X_{3}$ & $.541^{*}$ & $.567^{\star \star}$ & $.670^{\star \star}$ & 1.000 & & \\
\hline $\log X_{4}$ & $.357^{*}$ & $.371^{* *}$ & $.286^{\star *}$ & $.419^{\star *}$ & 1.000 & \\
\hline $\log X_{5}$ & $.351^{*}$ & $.388^{\star *}$ & $460^{\star *}$ &, $472^{\star}$ & $279^{\star *}$ & 1.000 \\
\hline $\log X_{6}$ & $207^{\star \star}$ & $188^{\star \star}$ & $301^{\star \star}$ & $308^{\star *}$ & 999* & $740^{* *}$ \\
\hline
\end{tabular}

\subsection{Regression Equation}

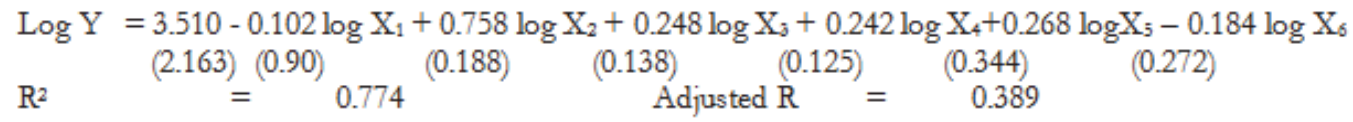

Figure in parenthesis are standard errors of the coefficients.

The $\mathrm{R}^{2}$ shows $77 \%$ indicating that the six independent variable could only explain $77 \%$ variation in total migration. 


\section{Conclusion and Recommendations}

Rural-urban migrations have been identified to reduce labour force available for cocoa production with its consequent decline in productivity or output. The study revealed that migration is highest between age breaket of 21-40 in the study area. The implication of this is that people migrant for social, educational and economic reasons. In order to reduce rural urban drift, it is recommended that government should provide more rural infrastructures which include: Rural physical infrastructures, rural social infrastructures, rural systems such as feeder roads, access roads, railroads, bridges, boats, port, footh parts etc. Government should also improve on the processing facilities such as public processing facilities, machinery, equipment etc. Communities systems such as rural telephone services, postal agencies should also be improved upon. Government should also provide more social infrastructures. This include health facilities such as hospitals, dispensaries, maternity, health centres etc; and educational facilities such as primary schools. Secondary schools and rural electrification. The fact must be stressed that rural infrastructures have beneficial production, income, employment, resource allocation and socio-economic welfare effects on rural communities.

Government should also provide credit facilities for the farmers. Effects should also be geared towards improving agricultural production price that will encourage urban-rural migration of youths. Sitting of agro-allied industries in the rural areas will also reduce rural-urban migration.

\section{References}

Adesimi A.A. (1977). "Urban Growth and its impact on Nigerians Agriculture Manpower”; Nigeria Geographical Journal 20 (1); 3640.

Adewuyi A.A. (1979). "Estimates of labour supply for the 1980s in Nigeria. Paper presented at the National Workshop on population and Economic development in Nigeria in 1980s. University of Lagos 1979.

Adepoju, A. (1975.) Internal migration in Nigeria.Proceedings of the seminar on internal migration in Nigeria.University of Ife, lle Ife.

Ajiboye S.O (2000): Impact of food production in Nigeria. A Seminar Paper presented to the Department of Agricultural Extension and Management. Federal College of Agriculture, Akure.

Byerlee D. (1974)."Rural- Urban Migration in Africa.Theory, policy and research implication". International migration Review Vol. 8, No 4 (Winter 1974): 543- 566.

Callaway A. (1969). Education Expansion and the rise of youths Unemployment in the city of Ibadan, Edited by P.C Lliyd. All Mabogunye \& BAWC, London Cambridge University Press.

Ekong E. Ekong (1988): An Introduction to Rural Sociology. Page 55-74. Onibonoje Press.

Imoagene, S.O. (Nov. 1967) "Psycho-social factors in rural-urban migration". Nigerian Journal of Economic and Social Studies.Vol.9.no.3.

Mabogunje, A.L. (1972). Regional Mobility and Resource Development in West Africa. Montreal: McGill-Queens University Press.

Mabawonku .A.F. (1973) "Impact of Rural-Urban Migration in the Economy of Selected Rural Communities in Western Nigeria".Department of Agricultural Economics University of Ibadan.

Mitchel A. (1959) Economic Implication of Rural Urban Migration. Seminar Paper presented at the Workshop in I.A.R.\&T.

Olusanya P.O (1969) "Socio-Economic aspect of Rural Urban migration in Western Nigeria.Nigeria Institute of Social and Economic Research, Ibadan.

Okuneye, P.A. (1989) "Migration and Agricultural Production towards a new form of Rural development policy in Nigeria.Problem and Prospects Nigeria Sociological Association.

Onibokun \& Adegbola (1988) Socio-economic effects of Rural Urban Migration in Western Nigeria. Nigeria Journal Vol.2, page 3-5.

Sada P.O. (1972): Urban Poverty. "The case of Lagos in O. Teriba (ed.).Poverty in Nigeria, Nigerian Economic Society.

Todaro, M.P. (1969): A model of labour Migration and Urban Unemployment in less developed Countries. American Economic ReviewMarch.

Todar M.P; , (1976.) Internal Migration in Developing Countries. A World Employment Study General: ILO.

Torimori, D.O. (1995): From Ministry to Farm. A suggested policy for rural food production in Nigeria, Management of Rural Resources, Edited by Oludimu .O.

Udo, R.K, (1975). Migrant Tenant farmers of Nigeria, Lagos: African University Press. 